\title{
Serbian heavy clays behavior: Application in rouch ceramics
}

\author{
Milica V. Arsenović ${ }^{1}$, Lato L. Pezo ${ }^{2}$, Zagorka M. Radojević ${ }^{1}$, Slavka M. Stanković ${ }^{3}$ \\ ${ }^{1}$ Institute for testing of materials IMS, Bulevar vojvode Mišića 43, 11000 Belgrade, Serbia \\ ${ }^{2}$ University of Belgrade, Institute of general and physical chemistry, Studentski trg 12, 11000 Belgrade, Serbia \\ ${ }^{3}$ Faculty of Technology and Metallurgy, University of Belgrade, Karnegijeva 4, 11000 Belgrade, Serbia
}

\begin{abstract}
This study is focused on the behavior of five new deposits of heavy clays from Serbia, with the aim to evaluate their potential suitability as raw materials in rough ceramic applications. The Pfefferkorn plasticity coefficient (PC) and drying susceptibility using Bigot's curve were measured for each raw sample. Thermodilatometric analysis (TDA) showed the behavior of dry products during firing. Samples groups were fired in the range of 850-1000 ${ }^{\circ} \mathrm{C}$. Water absorption capacity (WAC) and compressive strength (CS) measurements were done in order to characterize the clays after firing. Linear regression models were used to fit the results. Mathematical tools were used to determine statistical difference of major oxides content, shaping moist and compressive strength of dry laboratory products, using post-hoc Tukey's HSD test. The chemical and mineralogical compositions of samples do not differ considerably, but their possible application does. All studied clays seem to be easily adaptable to a correct brick making process.
\end{abstract}

Keywords: heavy clay, technological characteristics, application.

\section{SCIENTIFIC PAPER}

UDC 553.6(497.11):666.3

Hem. Ind. 67 (5) 811-822 (2013)

doi: 10.2298/HEMIND121123006A

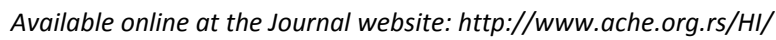

Clays and clay minerals have been widely used as the main raw materials in the fabrication of rough ceramic products for construction materials due to many specific properties before and after firing. The study of mineral phases present in the raw material is rather difficult, because industrial clays have a very complex mineralogical composition. During the firing process, a series of transformations occur, which affect the final properties of the ceramic products. Plasticity, chemistry, color, mechanical strength after firing, water absorption capacity etc. are the important properties of clay that are of interest to the ceramics industry [1]. The knowledge of these characteristics leads to optimization of the use of new clay deposits in local or regional ceramic industries.

During the ceramic process, once the crystalline structures of minerals exceed their stability limits, they are partially decomposed while others are simultaneously formed. The high temperature, low-pressure mineral transformations are mainly influenced by the chemical and mineralogical compositions of the original clay, its grain-size distribution, the maximum heating temperature, heating rate, duration of firing and kiln atmosphere. The knowledge of the physicochemical behavior of the clays is essential when exploring suitable compositions required for rouch ceramics production. Common components that play fundamental roles

Correspondence: M.V. Arsenović, Institute for testing of materials IMS, Bulevar vojvode Mišića 43, 11000 Belgrade, Serbia.

E-mail: milica.arsenovic@institutims.rs

Paper received: 23 November, 2012

Paper accepted: 10 January, 2013 for optimum processing and performance of the final products are kaolins for plasticity, silica as filler, and feldspar as fluxing agent to lower the temperature required for formation of a vitreous phase that promotes densification $[2,3]$.

The masonry industry in Serbia was founded in 1866. According to the Association of Clay Products industry data, until recently there were about 90 brick factories, of which more than a half used primitive production technology, which had been for two decades completely abandoned in Europe. Nowadays, with more foreign investors and major manufacturers, the situation has changed significantly. The number of facilities is reduced and product quality requirements are increased in coordination with the European Norms.

Loess (both onshore and swamp) in north Serbia is mostly used in the brick industry, and therefore belongs to the brick raw materials. Almost the entire production of solid bricks is based on loess, mostly in small factories at a low level of technology and equipment. Favorable particle size distribution, low shrinkage and sensitivity to drying and firing lead to much easier production. The presence of carbonates in loess in the form of large concretions and "loess dolls" is common. Such material is not suitable for the application, or requires special processing line with a cleaner and multiple grinding in degrees of granularity below $0.5 \mathrm{~mm}[4,5]$.

One of the main factors currently preventing realization of the potential of local materials in Serbia is insufficient scientific analyses. Serbian clays have been often characterized, but in the literature there are very few presented studies on the quality and potential use, 
although clay is a primary material for local ceramic manufacturers [3-8]. For this reason, particular attention should be paid to the investigation of clay deposits in Serbia for ceramic applications. The raw clay materials from non-exploited deposits presented in this paper were neither tested for masonry production, nor characterized. This is the first detailed, multi-level analysis of interest from an academic and technological viewpoint. The main objective of this work is determination of chemical and mineralogical compositions, as well as technological behavior that altogether allows the evaluation of the applicability of the clay deposits studied, while giving a picture on the quality of the clay from Serbia from different localities.

\section{EXPERIMENTAL}

This paper presents the ceramic and technological behavior of five new opened clay deposits in Serbia, which can be used in the formulation of masonry raw materials mix. The clays originate from Svilajnac (SV), Jagnjevo (JG), Mala Plana (MP), Leskovac (LE) and Novi Pazar (NP). These clays are representative raw materials that reflect the similarities and differences in the quality and possible application.

After collecting, the samples were dried in the oven at $105 \pm 5{ }^{\circ} \mathrm{C}$ until constant mass and then milled following the usual practice in ceramic laboratories. The clays were moistened and mixed with about $24-26 \%$ of water. They were left to rest for $24 \mathrm{~h}$ in sealed nylon bags to obtain homogenous moist distribution. The shaping process was done following the usual procedure [8] using a laboratory extruder (Händle). Laboratory samples are produced in the form of tiles (120 $\mathrm{mm} \times 50 \mathrm{~mm} \times 14 \mathrm{~mm}$ ), hollow blocks with vertical voids (55.3 $\mathrm{mm} \times 36 \mathrm{~mm} \times 36 \mathrm{~mm}$ ) and cubes (30 mm $\times 30$ $\mathrm{mm} \times 30 \mathrm{~mm}$ ).

Firing was done in the oxygen atmosphere kiln, with average heating speed of $1.4{ }^{\circ} \mathrm{C} / \mathrm{min}$ until $610{ }^{\circ} \mathrm{C}$, and later with the rate of $2.5{ }^{\circ} \mathrm{C} / \mathrm{min}$ until the final given temperature was reached, at which the samples were treated for $2 \mathrm{~h}$. Firing was conducted at 850, 900, 950 and $1000{ }^{\circ} \mathrm{C}$. Properties of dry and fired samples are presented, with the suggested ways of applying the tested materials for certain products.

In order to precisely define the technological characteristics of brick raw materials from new locations in Serbia, it is necessary to determine their chemical, mineralogical and granulometric composition. Three samples for each deposit were analyzed to obtain the mineralogical and chemical compositions (average values are shown and discussed).

Granulometry analysis was done by the sieve and pipette method, after drying at room temperature. The sample was dipped in distilled water for $24 \mathrm{~h}$, and then gently boiled for $1 \mathrm{~h}$. The cooled suspension was sieved on the $0.063 \mathrm{~mm}$ sieve, the fraction was dried and measured, and later the filtrate was treated in an ultrasonic bath for $30 \mathrm{~min}$. Samples were taken by pipette at appropriate intervals. Due to the size of particles in the sample NP, it was necessary to do sedimentation analysis (fractions under $0.063 \mathrm{~mm}$ ).

The mineralogical analysis was carried out by X-ray diffraction (XRD) using a powder diffractometer (Philips $\mathrm{PW}-1050)$ with $\lambda \mathrm{Cu}-\mathrm{K} \alpha$ radiation and scanning speed $0.05 \%$, both on powder (bulk samples) and oriented aggregates (treated with ethylene glycol and heated to $450{ }^{\circ} \mathrm{C}$ for $2 \mathrm{~h}$ ) of the clay fraction obtained, following the criteria described in the literature [9].

The chemical analysis was performed by classical silicate, gravimetric analysis $[3,10]$. Loss on ignition (LOI) was determined by standard procedure [11].

The Pfefferkon method was used to determine the plasticity coefficient (PC) as described in the literature [12]. After moistening and shaping of tiles, the mass is used to obtain the drying capacity of the clays by using a barelattograph to trace Bigot's curve.

The water absorption capacity (WAC) was determined in fired clay pieces by soaking in distilled water for $24 \mathrm{~h}$, according to standard EN 771-1 [13]. The laboratory hollow blocks compressive strength was tested in a laboratory hydraulic press, according to standard EN 772-1 [14].

Thermodilatometric analysis (TDA) was carried out using a Linseis dilatometer with a rhodium oven and thermopar platina - rhodium (L76). Firing conditions were such that the temperature increment was 10 ${ }^{\circ} \mathrm{C} / \mathrm{min}$, and the sample was held up at the final temperature of $1000{ }^{\circ} \mathrm{C}$ for $1 \mathrm{~h}$. This technique consists in measuring the length of a sample as a function of the temperature, allowing the study of the sintering process. The extruded sample was dried overnight at 105 ${ }^{\circ} \mathrm{C}$ and then heated in the dilatometer. Length changes were recorded every minute during the heating stage. Descriptive statistical analyses for calculating the means and the standard error of the mean were performed using Microsoft Excel 2007 software. All obtained results were expressed as the mean \pm standard deviation $(S D)$. Regression analysis and the evaluation of one-way analysis of variance (ANOVA) of obtained results were performed for comparison of means, and significant differences are calculated according to post-hoc Tukey's HSD test at the $p<0.05$ level, using StatSoft Statistica 10 software.

\section{RESULTS AND DISCUSSION}

\section{Granulometry and mineralogy}

Granulometry analyisis gave the information about particle size and their quantity (in \%), as presented in Figure 1. Based on these results, Figure 2 is obtained, 
where clay $(<2 \mu \mathrm{m})$ and sand sized particles $(>50 \mu \mathrm{m})$ are observed. The rest of the material (until 100\%) presented allevrite $(2-50 \mu \mathrm{m})[15]$.

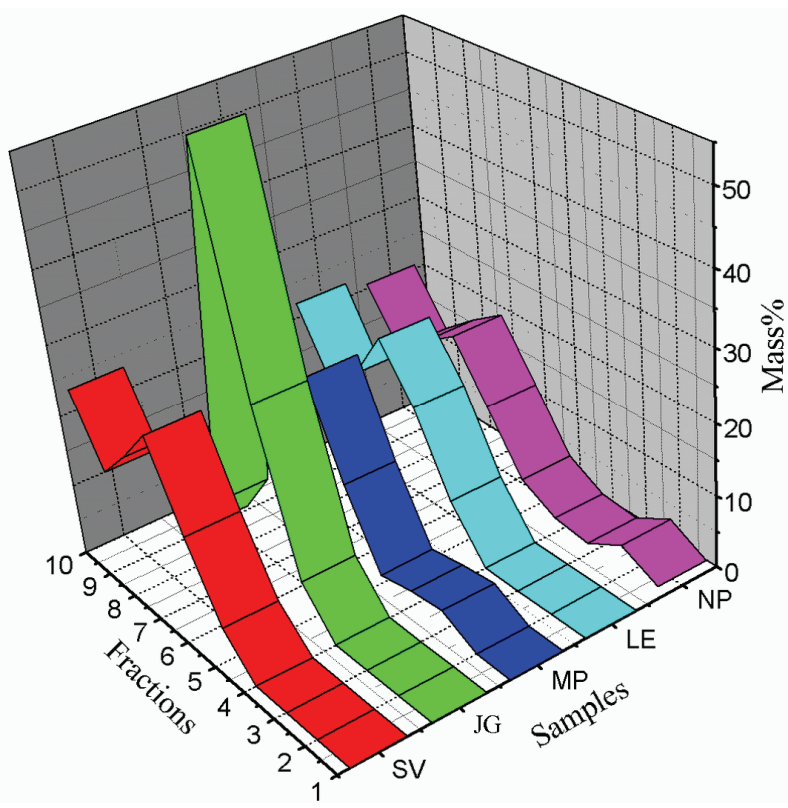

Figure 1. The particle size distribution (in $\mathrm{mm}$ ): $1-2.0,2-1.0$, $3-0.5,4-0.125,5-0.063,6-0.032,7-0.016,8-0.008$, $9-0.004,10-0.001$.
Soil texture is presented according to Unified Soil Classification System (Figure 2). All the samples belong to allevrite type sediments (silt fraction), where NP showed the highest level of sand $(19.42 \pm 0.99 \%)$, JG of allevrite $(87.53 \pm 4.19 \%)$ and MP of clay $(28.85 \pm 1.73 \%)$. The samples SV and MP belong to silty clay loam, LE and NP are defined as silty loam, while JG represents silt.

The particle size distribution could have an effect on the bulk density and compressive strength of the green body, which should be dependent on the way in which the particles are packed. Better particle packing is obtained when finer particles fill the void space between the larger particles.

Characteristics of good plasticity and high levels of water absorption are linked to the fraction of the particles less than $2 \mu \mathrm{m}$ in size, which represents the clay fraction. A high content of this fraction gives plasticity in conjunction with high initial water content and drying problems due to the high drying shrinkage. Higher proportions of finer particles in the raw material favour vitrification due to the good compaction of samples during moulding, and this has a positive influence on resistance of fired samples [16]. The content of fraction below $2 \mu \mathrm{m}$ is similar in SV, MP, LE and NP and ranges between $23.89-28.85 \%$, while sample JG contains only $0.69 \pm 0.03 \%$ of clay, which remarkably affects its ceramic and technological properties.

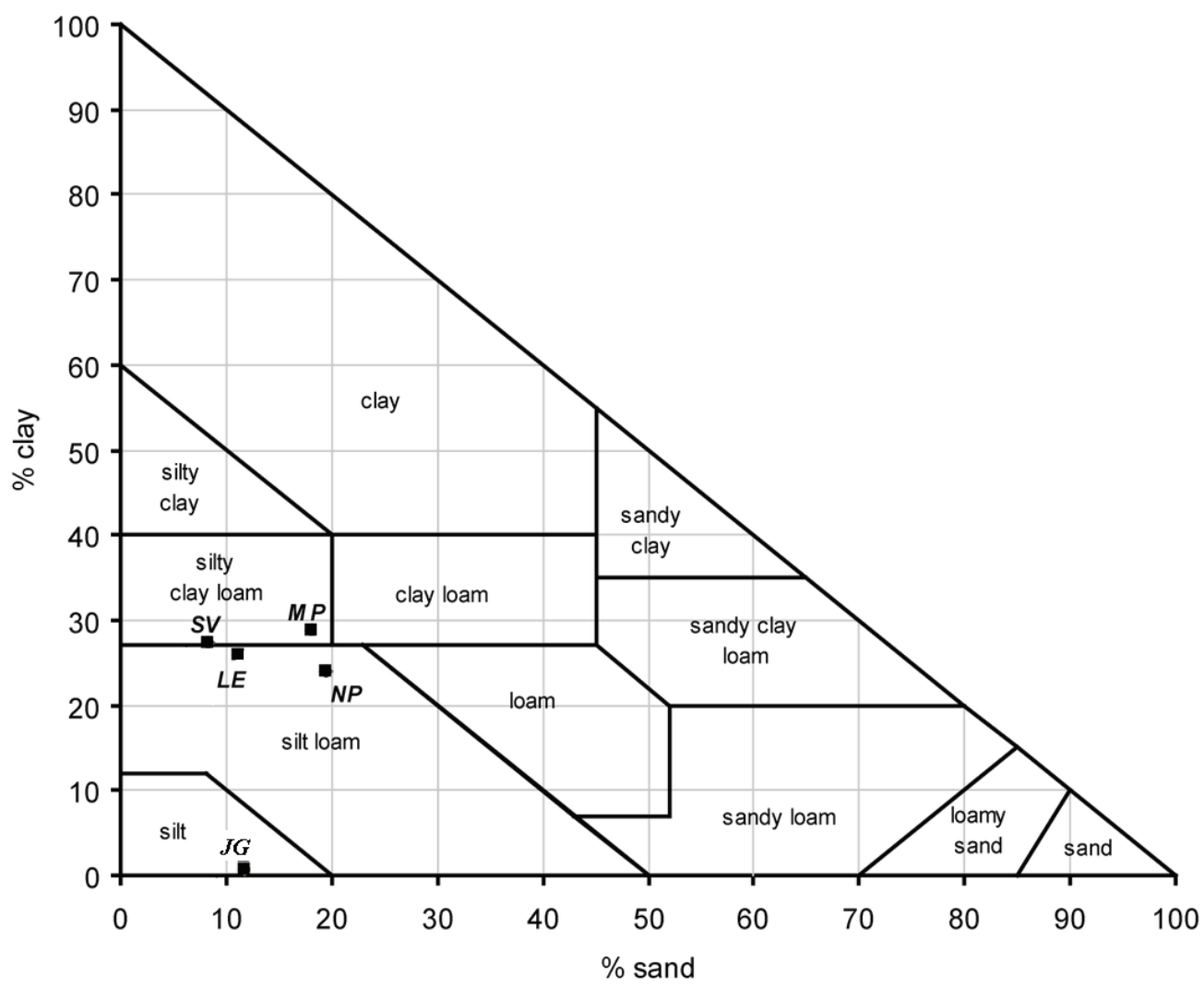

Figure 2. Samples texture diagram. 
Optimal compositions of material mixtures can be based on the granulometric composition of soil using the Winkler diagram [17], the traditional way to roughly determine the possible usage of raw materials in certain brick products (for example soid bricks, hollow blocks and roofing tiles). The samples tested did not belong to any group, according to Winkler's diagram. Particle size distribution (Figure 1) showed that all the samples mostly contained particles between 8 and $32 \mu \mathrm{m}$, and JG even $58.5 \pm 2.37 \%$ of $16-32 \mu \mathrm{m}$ particles. The largest particles were observed in NP, which had $1.68 \pm 0.05 \%$ of $>2.0 \mathrm{~mm}$ and $4.36 \pm 0.05 \%$ of $>1.0$ $\mathrm{mm}$ particles. The problem that can arise from the presence of coarser particles can be solved by simply crushing and sifting. Generally, particles below $53 \mu \mathrm{m}$ are called the "plasticity fraction" because they provide the necessary plasticity for shaping, combined with strength for handling wet products. The particle size distribution in moistened raw material also depends on the water content [12]. This means that the Winkler diagram cannot be taken literally.

The mineralogical composition of all the samples was dominated by quartz and layered silicates (Table 1). All the samples showed very similar clay composition: mica, chlorite and smectite were found. Low detected amounts of layered silicates were in JG in the case of smectite, and in LE chlorite. The sample SV also contained a low amount of kaolinite.

It is known that red-firing clays are rich in mica [18]. Decomposition of unstable illite leads to formation of mica by isostructural replacement. Micas belong to primary minerals, which have larger particles then clay minerals (fractions usually greater than $10 \mu \mathrm{m}$ [19]. Because of the possibility of isostructural substitution of aluminum in octaeder and silicon cations in the tetrahedral configuration with the other cations, there are many minerals that are montmorillonite-like, with a common name smectites $[12,20]$. Smectite shows a good plasticity behavior, it is an expanding clay mineral that dries hard [21]. The absence of a significant amount of smectitic minerals will ensure a ceramic body against possible difficulties during drying [22]. In principle, the illite and smectite are clay brick essential ingredients because they sinter at relatively low temperatures [18].

Calcite was found in most of the samples (SV, MP and LE) in low proportions. Samples JG and NP showed larger contents of calcite, while JG also showed presence of dolomite. Feldspars are mainly present in low rates in the form of plagioclase (JG, LE, NP and MP). Other feldspar minerals - amphiboles, are also detected in low rate in the sample MP. These different types of clay raw materials do not present great differences in mineralogical composition.

\section{Chemical composition}

The five clays present the expected typical compositions (Table 2), rich in silica and alumina, with satisfying content of potash, minor contents of titan, phosphorus and sulfur, accompanied by a significant amount of iron oxides. The post-hoc Tukey's HSD tests were evaluated for comparison between oxides content in samples, and statistically significant differences were found between all samples, significant at $p<0.05$ level.

In the chemical compositions of heavy clay, high quartz content is mainly related to $\mathrm{SiO}_{2}$ percentages. The $\mathrm{Al}_{2} \mathrm{O}_{3}$ content is correlated to clay minerals. $\mathrm{K}_{2} \mathrm{O}$ and $\mathrm{Na}_{2} \mathrm{O}$, first of all, presume the presence of mica, then $\mathrm{K}$ feldspar and $\mathrm{Na}$ feldspar contents. High $\mathrm{MgO}$ content indicates dolomite $[3,5]$. By viewing the con-

Table 1. Mineralogical composition of the studied clays; $Q$ - quartz; layered silicates ( $M-$ mica, $C h$ - chlorite, Sm - smectite, $K-k a o-$ linite), carbonates ( $C$ - calcite, $D$ - dolomite), $F$-feldspars ( $P$ - plagioclase, $A$-amphiboles), +- present, $+_{1}-$ present in low rate

\begin{tabular}{|c|c|c|c|c|c|c|c|c|c|}
\hline \multirow{2}{*}{ Sample } & \multirow{2}{*}{$Q$} & \multicolumn{4}{|c|}{ Layered silicates } & \multicolumn{2}{|c|}{ Carbonates } & \multicolumn{2}{|c|}{$F^{a}$} \\
\hline & & $\mathrm{M}$ & $\mathrm{Ch}$ & $\mathrm{Sm}$ & K & $\mathrm{C}$ & $\mathrm{D}$ & $P$ & $A$ \\
\hline SV & + & + & + & + & $t_{1}$ & $t_{1}$ & & & \\
\hline$J G$ & + & + & + & $t_{1}$ & & + & + & $+_{1}$ & \\
\hline MP & + & + & + & + & & $t_{1}$ & & $+_{1}$ & $+_{1}$ \\
\hline LE & + & + & $+_{1}$ & + & & $+_{1}$ & & $+_{1}$ & \\
\hline NP & + & + & + & + & & + & & $+_{1}$ & \\
\hline
\end{tabular}

Table 2. Macroelements content (mass\%); values with the same letter, written in superscript are not statistically different at the $p<0.05$ level, 95\% confidence limit, according to post-hoc Tukey's HSD test

\begin{tabular}{|c|c|c|c|c|c|c|c|c|c|c|c|}
\hline Sam & $\mathrm{SiO}_{2}$ & $\mathrm{Al}_{2} \mathrm{O}_{3}$ & $\mathrm{Fe}_{2} \mathrm{O}_{3}$ & $\mathrm{aO}$ & 0 & $\mathrm{Na}_{2} \mathrm{O}$ & $\mathrm{K}_{2} \mathrm{O}$ & $\mathrm{TiO}_{2}$ & $\mathrm{P}_{2} \mathrm{O}_{5}$ & $\mathrm{SO}_{3}$ & LUI \\
\hline SV & $2.60 \pm 1.40^{c}$ & & $6.76 \pm 0.29^{b}$ & $2.56 \pm 0.10^{b}$ & $16 \pm 0.07^{a}$ & $1.02 \pm 0.05^{\mathrm{a}}$ & $3.14 \pm 0.13^{\mathrm{a}}$ & $0.75 \pm 0.04^{\mathrm{a}}$ & $0.24 \pm 0.01^{b}$ & $0.00 \pm 0.00^{\mathrm{a}}$ & $7.45 \pm 0.24^{a}$ \\
\hline$G_{1}$ & 4 & & 4.00 & $11.50 \pm 0.25^{\mathrm{e}}$ & $5.98 \pm 0.24^{\mathrm{e}}$ & $1.58 \pm 0.07^{b}$ & $3.07 \pm 0.12^{\mathrm{ab}}$ & $0.55 \pm 0.01^{b}$ & $0.15 \pm 0.01^{\mathrm{a}}$ & $0.04 \pm 0.00^{b}$ & $5.39 \pm 0.66$ \\
\hline ת & $=27$ & & $7.86 \pm 0$ & $3.46 \pm 0.12^{c}$ & $3.43 \pm 0$. & $1.50 \pm 0.01^{b}$ & $3.20 \pm 0.15^{\mathrm{a}}$ & $1.15 \pm 0.06^{c}$ & $0.09 \pm 0.00^{c}$ & $0.00 \pm 0.00^{\mathrm{a}}$ & $9.14 \pm 0.37^{b}$ \\
\hline & & & $8.07 \pm 0.20^{\mathrm{a}}$ & $1.50 \pm 0.11^{\mathrm{a}}$ & $1.92 \pm 0.10^{b}$ & $0.81 \pm 0.02^{c}$ & $2.75 \pm 0.11^{b}$ & $0.74 \pm 0.03^{\mathrm{a}}$ & $0.25 \pm 0.01^{b}$ & $0.00 \pm 0.00^{\mathrm{a}}$ & $8.00 \pm 0.38^{\mathrm{ab}}$ \\
\hline & $9.42 \pm 0.67^{\mathrm{a}}$ & $17.87 \pm 0.48^{c}$ & $7.51 \pm 0.33^{\mathrm{ab}}$ & $7.25 \pm 0.44^{d}$ & $2.37 \pm 0.12^{c}$ & $1.12 \pm 0.03^{\mathrm{a}}$ & $3.14 \pm 0.09^{\mathrm{a}}$ & $0.75 \pm 0.03^{\mathrm{a}}$ & $0.15 \pm 0.01^{\mathrm{a}}$ & $0.07 \pm 0.00^{c}$ & $=10.60 \pm 0.1$ \\
\hline
\end{tabular}


tent of major oxides in clay minerals given in literature [19], it can be observed that the highest content of aluminum is in kaolinite, potassium in illite and sodium in montmorillonite. These results confirm the mineralogical content as described previously.

The amount of silica $(49.42 \pm 0.67$ to $62.60 \pm 1.40 \%)$ was relatively high in all the samples. The $\mathrm{Al}_{2} \mathrm{O}_{3}$ content varied between $10.50 \pm 0.39$ and $17.87 \pm 0.48$ mass $\%$, depending on the content of clay minerals. Actually, these clays consist mainly of $\mathrm{SiO}_{2}$ and $\mathrm{Al}_{2} \mathrm{O}_{3}$ (overall $57.60-76.60 \%$ ) showing the dominant presence of quartz and clay minerals. Relatively high amount of $\mathrm{Fe}_{2} \mathrm{O}_{3}(4 \pm 0.23$ to $8.07 \pm 0.20 \%)$ regards these samples as acceptable for use in rough ceramics. The amount of the earth-alkaline oxides ( $\mathrm{CaO}$ and $\mathrm{MgO}$ ) is low, indicating that the studied red clay is not so rich in carbo-

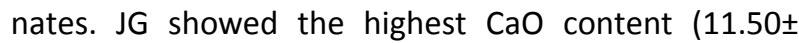
$\pm 0.25 \%)$ and loss on ignition $(15.39 \pm 0.66 \%)$ due to the decomposition of calcium carbonates, and probably the content of organic carbon in allevrite. This result agreed with that of calcimetry tests (not shown in this work). After microscopic identification of $0.063 \mathrm{~mm}$ sieve residue, it is determined that sample JG had shells remains and loess fragments.

Most of the samples (SV, JG, MP and NP) showed high relative amounts of alkaline oxides $\left(\mathrm{Na}_{2} \mathrm{O}+\mathrm{K}_{2} \mathrm{O}\right)$, which, in reaction with silica and alumina, promote liquid phase formations that facilitate densification, explaining why samples sinter at relatively low temperatures [23]. The loss on ignition was in the range of $7.45 \pm 0.24$ to $15.39 \pm 0.66 \%$, and can be, besides carbonates, attributed to the presence of clay minerals, hydroxides and organic matter [16].

Some harmful constituents such as sulfur compounds, which can cause efflorescence [21], were not detected in some of the samples (SV, MP and LE), and were found in low quantities $(0.08 \pm 0.001 \%)$ in $J G$ and NP samples.

\section{Color}

The color of clay bricks generally depends on the mineralogical composition of raw materials, temperature and firing conditions. Aluminum oxide $\left(\mathrm{Al}_{2} \mathrm{O}_{3}\right)$, iron oxide $\left(\mathrm{Fe}_{2} \mathrm{O}_{3}\right)$ and calcium oxide $(\mathrm{CaO})$ are responsible for the final product color. The dominant influence belongs to iron (III). The color of natural iron oxides and hydroxides varies from orange to red, depending on the type and degree of crystallinity and therefore influences soil color. Brick raw materials contain iron mainly in the form of minerals from the hydroxide group (goethite, limonite). In the process of burning, iron hydroxide is transformed into hematite, which gives the ceramic body characteristic color. The transformation of hydroxide into oxide by dehidroxilation begins at a temperature of about $300{ }^{\circ} \mathrm{C}$, and with the achievement of $400{ }^{\circ} \mathrm{C}$, the oxide is formed. The degree of oxidation greatly depends on the heating regime and the atmosphere in the furnace $[6,18]$. The yellow color of a fired product may come from calcium or aluminum oxide if the iron content is low, when iron (III) oxide associates with silicates [24]. For raw clay brick samples, the contents of oxides that affect the color are given in Table 2. After calculation of oxides important for color to $100 \%$, Figure 3 can be constructed. The ternary diagram shows the color differences between the samples according to Piltz [25].

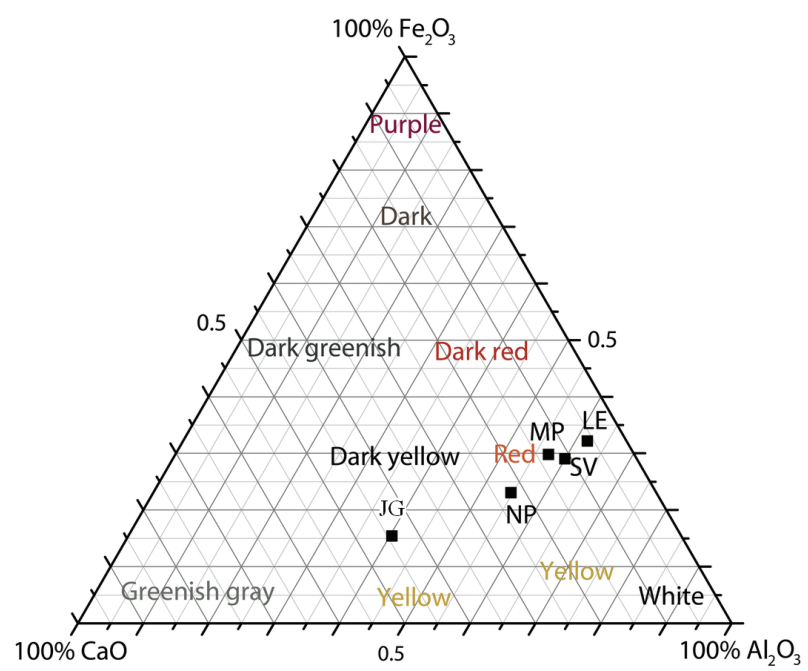

Figure 3. Three-component diagram showing fired brick color differences.

From the results shown in Table 2 and the diagram shown in Figure 3, the color of all fired samples is red with some hue differences. LE, MP and SV were of the most intensive red color, while firing at the higher temperatures $\left(950\right.$ and $1000{ }^{\circ} \mathrm{C}$ ) gave a darker hue. Similar behavior was observed with NP samples, bearing in mind that they were of brighter red color. The JG sample was of redish yellow color at all firing temperatures.

\section{Ceramic and technological tests}

In order to define the behavior of raw clay materials from Serbia in the technological process of brick production, it is important to define their technological and ceramic characteristics. Test results are shown in tables and graphs, and include: properties of materials after processing, homogenization and shaping, the behavior of raw materials in the process of drying and dry product characteristics and technological features of fired products.

\section{Raw material and green samples}

Table 3 shows important parameters concerning raw materials and dry samples. The post-hoc Tukey's HSD tests were evaluated for comparison between the molding moisture and dry compressive strength, and 
Table 3. Properties of materials after processing and drying; values with the same letter, written in superscript are not statistically different at the $p<0.05$ level, 95\% confidence limit, according to post-hoc Tukey's HSD test

\begin{tabular}{|c|c|c|c|c|c|}
\hline Parameter & SV & JG & MP & LE & NP \\
\hline Molding moisture (\%) & $24.23 \pm 0.07^{a}$ & $24.71 \pm 1.06^{a}$ & $24.34 \pm 0.25^{a}$ & $25.56 \pm 0.80^{a}$ & $24.52 \pm 1.64^{a}$ \\
\hline Dry compressive strength (MPa) & $16.30 \pm 0.28^{c}$ & $10.76 \pm 0.19^{\mathrm{a}}$ & $11.98 \pm 0.48^{\mathrm{a}}$ & $19.22 \pm 0.88^{b}$ & $19.25 \pm 0.59^{b}$ \\
\hline
\end{tabular}

statistically significant differences were found between all samples, significant at $p<0.05$ level (Table 3 ).

The quantity of water used to make plastic mass was similar for all the samples and in the range of $24.23 \pm 0.07$ to $25.56 \pm 0.80 \%$. The compressive strength of dry samples indicates the transport possibility of the products from the kiln to the dryer, so it is desirable to be as high as possible. A higher compressive strength will show samples with better packing and higher content of clay minerals, which are subjected to an appropriate drying regime. In our case the samples LE and NP behaved the best.

Plasticity is one of the most important rheological properties of raw materials for traditional ceramics, because it points to the possibility of forming clay bodies by application of pressure, and the mechanical properties of the product $[26,27]$. The mineralogical composition of the clays and the particle size distribution influence plasticity. The plasticity of clays is related to the morphology of the plate-like clay mineral particles that slide over the others when water is added, which acts as a lubricant. As the water content of clay is increased, the plasticity increases up to a maximum, depending on the nature of the clay [12]. The materials with the highest content of clay particles (SV, LE and MP) showed the most plastic features (Figure 4). The differences in the plasticities of the samples were almost understandable from the particle size distribution data (Figure 2). Varying amounts of quartz also influenced the plasticity and drying behavior of the clays [22].

The Pfefferkorn diagram is presented as a link between water content and material stiffness (Figure 4). Most of the samples (SV, MP, LE and NP) showed very high plastic behavior $(P C>30)$, explaining their excellent aptitude for pressing; only the JG sample had moderately plastic properties $(P C=24.5)$.

The experimental data obtained were fitted to linear regression models $(y=a+b x)$ solved by a Levenberg-Marguardt numerical method, and the results were examined using standard statistical error tests, i.e., coefficient of determination $\left(r^{2}\right)$, the mean relative percent error (MPE), the root mean square error (RMSE) and the reduced chi-square $\left(\chi^{2}\right)$. The higher the values of $r^{2}$ and the lower the values of MPE, RMSE and $\chi^{2}$, the better is the goodness of fit (Table 4). These parameters were calculated as follows:

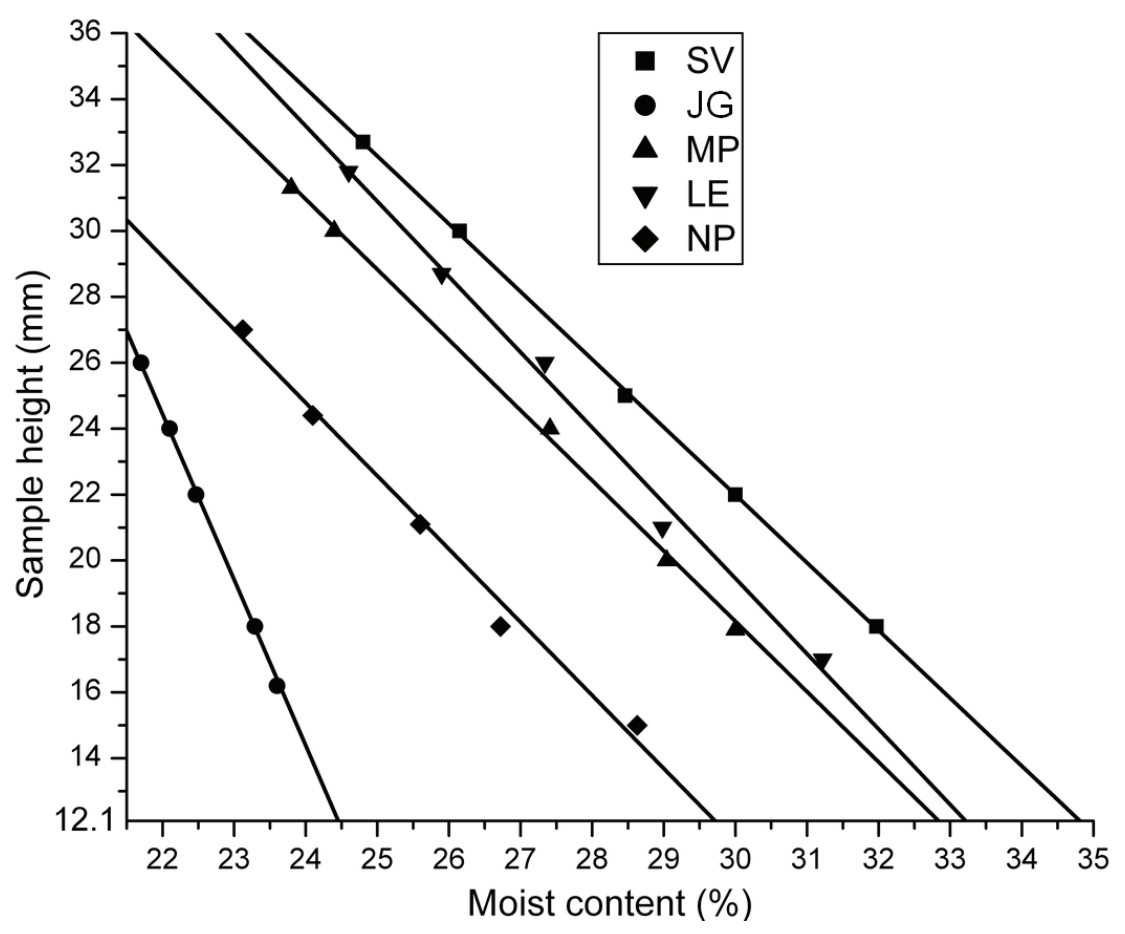

Figure 4. Plasticity determination of materials. 
Table 4. Linear regression model constants for plasticity determination by Pfefferkorn method; All constants were significant at $p<0.05$ level, 95\% confidence limit, according to ANOVA calculation

\begin{tabular}{|c|c|c|c|c|c|}
\hline Constant & SV & $J G$ & MP & LE & NP \\
\hline$a$ & $83.72 \pm 0.55$ & $137.06 \pm 1.42$ & $82.57 \pm 1.25$ & $87.79 \pm 3.01$ & $77.65 \pm 3.23$ \\
\hline$b$ & $-2.06 \pm 0.02$ & $-5.12 \pm 0.06$ & $-2.15 \pm 0.05$ & $-2.28 \pm 0.11$ & $-2.21 \pm 0.13$ \\
\hline$r^{2}$ & 0.999 & 0.999 & 0.999 & 0.993 & 0.990 \\
\hline$\chi^{2} \times 10^{2}$ & 1.24 & 0.997 & 6.50 & 31.9 & 31.9 \\
\hline$M P E \times 10^{12}$ & -1.49 & -5.32 & 0.308 & 0.662 & 0.66 \\
\hline$R M S E \times 10^{12}$ & 3.33 & 1.19 & 0.688 & 1.48 & 1.48 \\
\hline
\end{tabular}

MPE $=\frac{100}{N} \sum_{i=1}^{n} \frac{\left|y_{\exp , i}-y_{\mathrm{pre}, i}\right|}{y_{\exp , i}}$,

$R M S E=\left[\frac{1}{N} \sum_{i=1}^{n}\left(y_{\mathrm{exp}, i}-y_{\mathrm{pre}, i}\right)^{2}\right]^{1 / 2}$,

$\chi^{2}=\frac{\sum_{i=1}^{n}\left(y_{\exp , i}-y_{\mathrm{pre}, i}\right)^{2}}{N-n}$

where $y_{\text {exp, } i}$ is the $i$-th experimentally observed value, $y_{\text {pre, } i}$ is the $i^{\text {th }}$ mathematical model predicted value, $N$ is the number of observations and $n$ is the number model constants ( $n=2$, for linear model).

Bigot's curves with critical points $\left(K_{\mathrm{t}}\right)$ coordinates are given in Figure $5 . \Delta G_{\mathrm{k}}$ is mass loss, and $\Delta S_{\mathrm{k}}$ presents shrinkage in critical point. The drying capacities for the studied clay deposits were done in laboratory conditions, by drying in air for $24 \mathrm{~h}$ [28]. These curves were used as preliminary indicators in the choice of raw materials [27] for the ceramic industry.
According to the results, the behavior of SV, MP, LE and NP were somewhat similar, although they have different values of shrinkage and moisture at critical points. SV and LE clays showed the highest shrinkage, 8.02 and $7.99 \%$ respectively, due to their high plasticity coefficient and clay content, while consequently they have more problematic drying behavior and susceptibility. The sample MP shrunk by $6.85 \%$, and by contrast, JG and NP showed more suitable behavior, with respectively 3.58 and $5.37 \%$ shrinkage during air drying. Most of the tested samples are highly susceptible in drying process (mass loss during drying in the air at critical point, $\left.\Delta G_{k}>10\right)$, where SV should be the most carefully dried $\left(\Delta G_{k}=13.77 \%\right)$; followed by $M P\left(\Delta G_{k}=\right.$ $=12.44 \%), \operatorname{LE}\left(\Delta G_{k}=11.80 \%\right)$ and $N P\left(\Delta G_{k}=10.35 \%\right)$. The sample JG belonged to the susceptible clays group because of smectite absence $\left(\Delta G_{k}=8.40 \%\right)$. It is known that with higher sand content, the clay is less sensitive to drying [23].

In summary, increased dispersion of raw clay material together with the content of fine particles caused more shrinkage, greater plasticity, increased mecha-

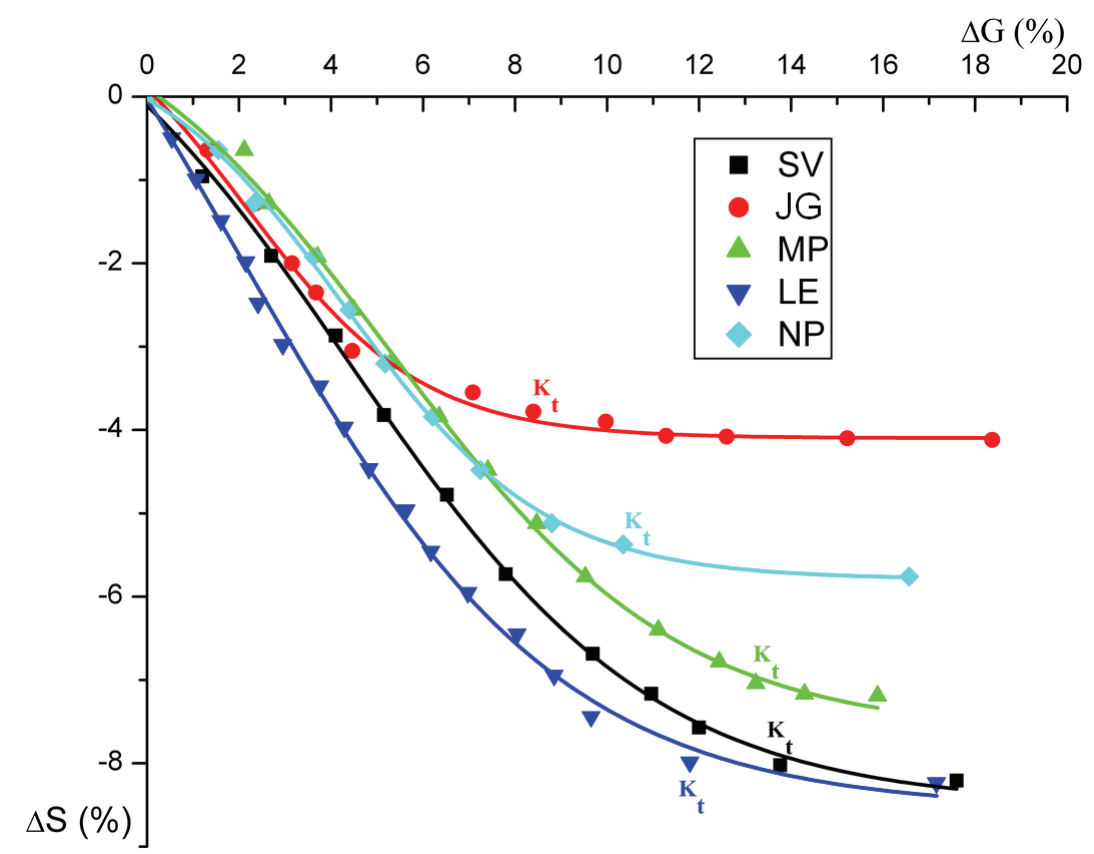

Figure 5. Bigot's curves of analyzed clay samples: $K_{t}$-critical point, $\Delta S_{k}-$ critical point shrinkage, $\Delta G_{k}-$ critical point mass loss. 
nical strength in the dry state and susceptibility during drying [12].

\section{Fired samples}

Raw materials characteristics and processing parameters affect the microstructure and final properties of ceramics, so it is necessary to test the behavior of samples as a function of the firing temperature [8]. The presence of minerals in different amounts influences the behavior of fired products. Depending on the characteristics of raw materials, the recommended firing regimes differ. Some researchers $[29,30]$ in the first part of the process, until a temperature of $600{ }^{\circ} \mathrm{C}$, practiced slow warming $\left(2-5{ }^{\circ} \mathrm{C} / \mathrm{min}\right)$ to avoid the appearance of cracks during the phase transformation of quartz at $573{ }^{\circ} \mathrm{C}$, with later increasing of heating rate to $5-10^{\circ} \mathrm{C} / \mathrm{min}$. The firing regime used in this research $\left(1.4^{\circ} \mathrm{C} / \mathrm{min}\right.$ until $610^{\circ} \mathrm{C}, 2.5^{\circ} \mathrm{C} / \mathrm{min}$ until the final temperature) was very slow and enough for all reactions to take place. All the tested samples were fired under the same regime in order to have comparable results. In order to optimize the mechanical properties of laboratory heavy clay products, water absorption is also a phenomenon that must be controlled [31].

Figure 6 shows the firing temperature dependence of compressive strength of the laboratory blocks and average water absorption capacity (WAC) of all extruded samples.

Compressive strength and water absorption results are fitted in the linear regression models, as already described in this paper, and presented in Table 5.

The samples SV, MP and LE showed similar behaviour, where at the higher temperature sample LE had the lowest water absorption value (and consequently

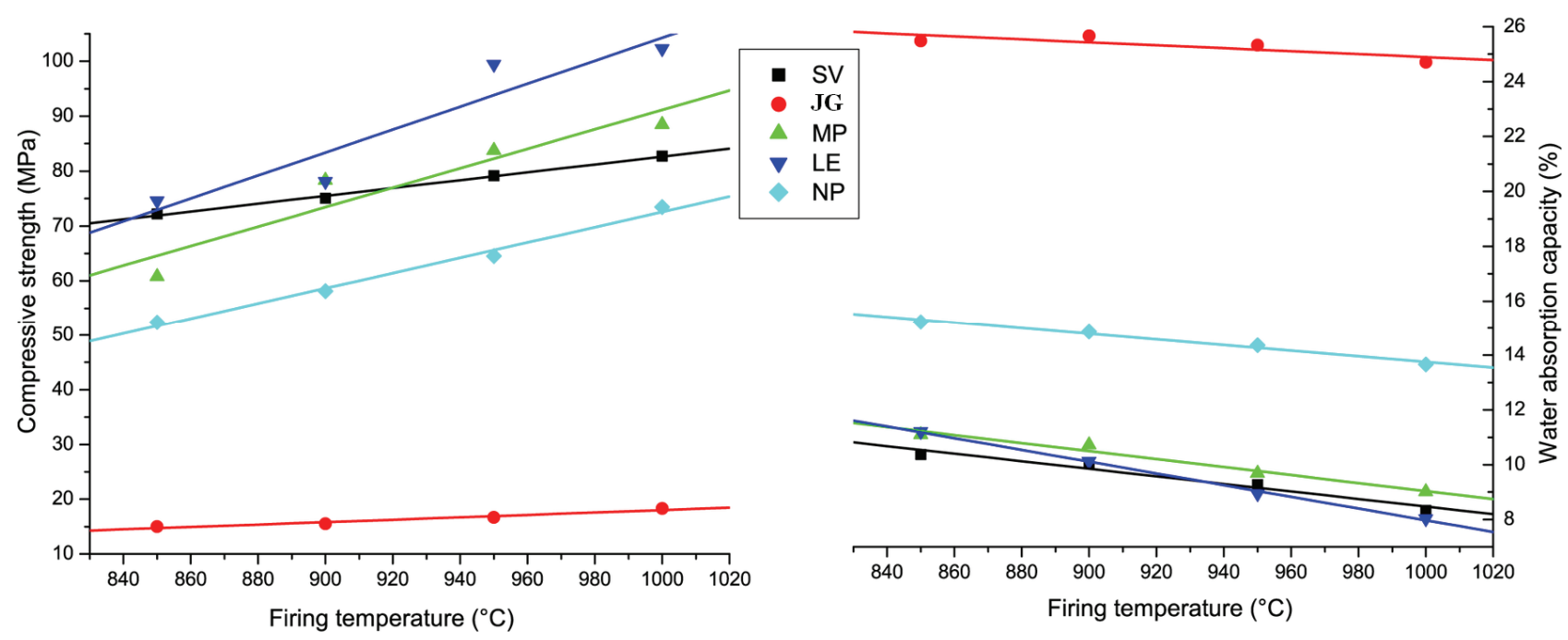

Figure 6. Compressive strength and water absorption depending on the firing temperature applied.

Table 5. Linear regression model constants for compressive strength and water absorption;

\begin{tabular}{|c|c|c|c|c|c|}
\hline Constant & SV & JG & MP & LE & NP \\
\hline \multicolumn{6}{|c|}{ CS } \\
\hline$a$ & $11.20 \pm 3.13^{\mathrm{a}}$ & $-3.99 \pm 3.00^{\mathrm{a}}$ & $-86.05 \pm 40.38^{\mathrm{a}}$ & $-104.61 \pm 47.64^{a}$ & $-66.61 \pm 9.48^{b}$ \\
\hline$b$ & $0.07 \pm 0.00^{b}$ & $0.02 \pm 0.00^{b}$ & $0.18 \pm 0.04^{\mathrm{a}}$ & $0.21 \pm 0.05^{\mathrm{a}}$ & $0.14 \pm 0.01^{b}$ \\
\hline$r^{2}$ & 0.998 & 0.946 & 0.892 & 0.892 & 0.989 \\
\hline$\chi^{2}$ & 0.425 & 0.174 & 0.237 & 0.330 & 1.31 \\
\hline$M P E \times 10^{12}$ & -8.19 & 74.9 & 0.725 & -0.188 & -0.712 \\
\hline$R M S E \times 10^{12}$ & 16.4 & 1.50 & 1.45 & 0.377 & 1.42 \\
\hline \multicolumn{6}{|c|}{ WA } \\
\hline$a$ & $22.27 \pm 1.86^{b}$ & $30.27 \pm 2.38^{b}$ & $23.66 \pm 1.63^{b}$ & $29.41 \pm 0.71^{b}$ & $24.17 \pm 1.03^{b}$ \\
\hline$b$ & $-0.01 \pm 0.00^{b}$ & $-0.01 \pm 0.00^{\mathrm{a}}$ & $-0.01 \pm 0.00^{b}$ & $-0.02 \pm 0.00^{b}$ & $-0.01 \pm 0.00^{b}$ \\
\hline$r^{2}$ & 0.959 & 0.886 & 0.972 & 0.997 & 0.978 \\
\hline$\chi^{2} \times 10^{2}$ & 5.03 & 8.27 & 3.85 & 0.729 & 1.54 \\
\hline$M P E \times 10^{12}$ & -0.327 & 449 & 0.427 & 0.167 & 0.00222 \\
\hline$R M S E \times 10^{12}$ & 0.655 & 898 & 0.854 & 0.335 & 0.00 .444 \\
\hline
\end{tabular}

${ }^{\mathrm{a}}$ Significant at $p<0.10$ level; ${ }^{\mathrm{b}}$ Significant at $p<0.05$ level 
the highest compressive strength). NP showed moderately high WAC level, and JG very high. The characteristics of the JG raw sample are responsible for the high values of water absorption and low compressive strength, due to the amount of carbonates (and the highest loss on ignition values). High porosity and water absorption observed in JG sample can be explained by its loess origin, meaning higher calcite content [4].

\section{Thermodilatometric analysis}

Dilatometric curves are used to determine the occurrence of densification in temperate regions as a function of the clay minerals content [30]. The dimensional change during firing of the $20 \mathrm{~mm}$ samples is shown in Figure 7.

The majority of raw materials, except JG, had no dimensional changes up to $97{ }^{\circ} \mathrm{C}$. Then, SV and NP began to shrink with the same intensity up to about $124{ }^{\circ} \mathrm{C}$, and then the collection ended with the NP already at about $146{ }^{\circ} \mathrm{C}$ for $6.8 \mu \mathrm{m}(0.034 \%)$, and with SV even at $245{ }^{\circ} \mathrm{C}$ for $26.5 \mu \mathrm{m}$ (0.13\%). A slight expansion followed by shrinkage between room temperature and $120{ }^{\circ} \mathrm{C}$ can be attributed to the loss of the adsorbed water. In some cases, adsorbed water removal can last even until $650^{\circ} \mathrm{C}$ [16]. LE mainly did not change the dimensions until the temperature of $220{ }^{\circ} \mathrm{C}$, after which it began to slightly shrink for about $24 \mu \mathrm{m}$ $(0.12 \%)$, with the end at $374{ }^{\circ} \mathrm{C}$. MP did not change the dimensions up to $338{ }^{\circ} \mathrm{C}$, when spreading occured. Between 450 and $650{ }^{\circ} \mathrm{C}$, all the samples shrank due to the dehydroxylation of clay minerals. Singer and Singer [32] pointed out that the transformation of quartz $\alpha$ to quartz $\beta$ occures at $573{ }^{\circ} \mathrm{C}$ with a volume increase of $2 \%$, and by further slow heating $\beta$-quartz changes to $\beta_{2}$-tridymite at $870{ }^{\circ} \mathrm{C}$ with a volume increase of $12 \%$. JG spreaded constantly until $579^{\circ} \mathrm{C}$, when all the samples started with the moderate expansion, with maxima from 678.5 (MP) to $834{ }^{\circ} \mathrm{C}$ (LE). The greatest expansion occured in JG $(205 \mu \mathrm{m}, 1.02 \%)$ and the lowest in MP (55 $\mu \mathrm{m}, 0.28 \%$ ), due to different quartz contents. Further shrinkage can be attributed to sintering, formation of vitreous phase, decarbonization and recrystallization of new ceramic phases [16]. After this period, most of the samples rapidly shrank until $1000{ }^{\circ} \mathrm{C}$. Vitrification occured at temperatures above $900{ }^{\circ} \mathrm{C}$ due to the significant presence of illite [33]. The sample JG began to spread rapidly at $927{ }^{\circ} \mathrm{C}$ for $166 \mu \mathrm{m}$ (0.83\%). It can be explained by the presence of dolomite (Table 1). Only this sample contained dolomite from the all five investigated samples, and it is known that dolomite decomposes completely above $900{ }^{\circ} \mathrm{C}$. The product resulting from this relatively low-temperature calcination is highly porous and reactive and is known as "calcinated dolomite".

\section{Possible applications of tested clays in rough ceramics}

Each ceramic product requires clays with particular and appropriate characteristics [16]. Based on chemical and mineralogical composition, as well as particle size distribution, analyzed deposits could be considered as

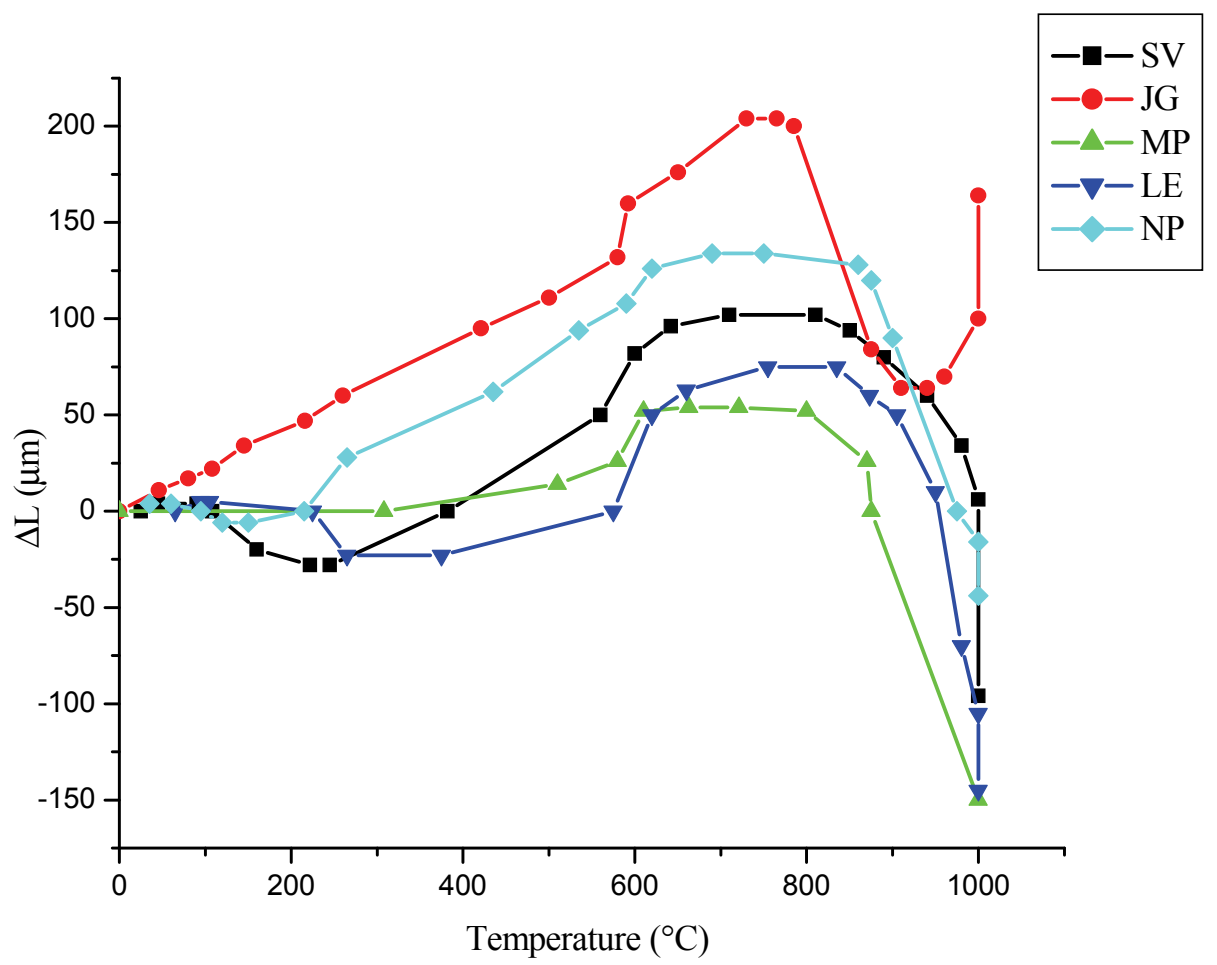

Figure 7. Dimensional change ( $\Delta L$ ) during heating up to $1000{ }^{\circ} \mathrm{C}$ (thermodilatometric curves). 
raw materials for use in rough ceramic products. All the studied clays seem to be easily adaptable to a correct ceramic process. It is recommendable to add sand for plasticity correction and reduction of susceptibility in drying in the samples SV, MP, LE and NP. Grinding below $1 \mathrm{~mm}$ is prefered because of the appearance of limestone concretions, and subsequent aging for equalization of rheological properties.

The tested SV, MP and NP samples had the highest clay sized particles content ( $24 \pm 1.12$ to $29 \pm 1.61 \%)$, so they can be used in the production of hollow bricks and blocks, as well as ceiling elements. As a primary raw material, these samples can be used in light-weighted bricks. In contrast, the JG sample is more suitable for the production of solid bricks, due to the low clay and high carbonates content, as well as the loess raw material nature, which causes low plasticity. In order to improve the product quality, more plastic clay should be added in the mixture for hollow blocks production. The JG sample can also be used to produce facade bricks, usually yellow colored, but firing must be carried out at relatively high temperatures $\left(1100-1150{ }^{\circ} \mathrm{C}\right)$. The LE sample, after grinding below $0.5 \mathrm{~mm}$ to avoid the appearance of lime corns, can be used in roof tiles and facade elements production.

\section{CONCLUSIONS}

Clays from different parts of Serbia were characterized by chemical, mineralogical, ceramic and technological analysis. All the samples contained mostly sand and clay minerals (mica, chlorite and smectite), with particles between 8 and $32 \mu \mathrm{m}$. Different mineralogical composition has a strong effect on the behavior of fired samples; consequently that is of decisive importance for the final quality of the end products.

The color of fired samples was red with some shade differences. All the samples except JG showed high plasticity and drying susceptibility. The possible usability of these raw materials in the manufacture of various rough masonry products, such as solid bricks, hollow bricks and blocks, ceiling elements and roof tiles depends on major differences in water absorption and compressive strength. All the studied clays seem to be easily adaptable to a correct brick making process. Most of the tested clays can be used as a primary raw material in the light-weighted brikcs production.

\section{Acknowledgement}

The authors are grateful for the financial support of the Scientific Research Projects of Serbian Ministry of Education, Science and Technological Development, Contract No. III450080.

\section{REFERENCES}

[1] B.K. Ngun, H. Mohamada, S.K. Sulaiman, K. Okadac, Z.A. Ahmada, Some ceramic properties of clays from central Cambodia, Appl. Clay. Sci. 53 (2011) 33-41.

[2] B.R. Ilić, A.A. Mitrović, Lj.R. Miličić, Thermal treatment of kaolin clay to obtain metakaolin, Hem. Ind. 64(4) (2010) 351-356.

[3] M. Arsenović, Z. Radojević, S. Stanković, Ž. Lalić, L. Pezo, What to expect from heavy clay?, Ceram. Int. 39 (2013) 1667-1675.

[4] Z. Radojević, Ž. Lalić, R. Vasić, A. Mitrović, Brick raw materials quality in Serbia and the influence for the products quality and to the production technology loess sediments, Izgradnja 59 (2005) 45-49.

[5] M. Arsenović, S. Stanković, L. Pezo, L. Mančić, Z. Radojević, Optimization of the production process through response surface method: Bricks made of loess, Ceram. Int. 39 (2013) 2013-2022.

[6] Z. Radojevic, M. Arsenovic, M. Vasic, Quality evaluation of south Serbia raw clay materials, Izgradnja 62 (2008) 157-161.

[7] M. Arsenović, S. Stanković, Z. Radojević, L. Pezo, Prediction and fuzzy synthetic optimization of process parameters in heavy clay brick production, Ceram. Int. (2013), doi: 10.1016/j.ceramint.2012.08.053.

[8] C.M.F Veira, R. Sanchez, S.N. Monteiro, Characteristics of clays and properties of building ceramics in the state of Rio de Janeiro, Brazil, Constr. Build. Mater. 22 (2008) 781-787.

[9] D.M. Moore, Jr., R.C. Reynolds, X-ray diffraction and the identification and analysis of clay minerals, Oxford University Press, Oxford, 1997.

[10] M.S. Ranđelović, M.M. Purenović, A.R. Zarubica, I.D. Mladenović, J.M. Purenović, M.Z. Momčilović, Fizičkohemijska karakterizacija bentonita i njegova primena $\mathrm{u}$ uklanjanju $\mathrm{Mn}^{2+}$ iz vode, Hem. Ind. 65(4) (2012) 381-387 .

[11] M.B. Dalmacija, M.D. Dalmacija, D.M. Krčmar, M.Đ. Prica, Lj.M. Rajić, S.D. Rončević, O. Gavrilović, Solidifikacija/stabilizacija sedimenta vodotoka Krivaja zagađenog metalima, Hem. Ind.66(4) (2012) 469-478 (in Serbian).

[12] M. Tecilazić - Stevanović, Osnovi tehnologije keramike, Faculty of Technology and Metallurgy, Belgrade, 1990 (in Serbian).

[13] EN 771-1:2010, Specification for masonry units - Part 1: Clay masonry units.

[14] EN 772-1:2010, Methods of test for masonry units - Part 1: Determination of compressive strength.

[15] J. Qian, X. Shan, Z. Wang, Q. Tu, Distribution and plant availability of heavy metals in different particle-size fractions of soil, Sci, Total. Environ. 187 (1996) 131-141.

[16] H. Baccour, M. Medhioub, F. Jamoussic, T. Mhiri, Influence of firing temperature on the ceramic properties of Triassic clays from Tunisia, J. Mater. Process. Tech. 209 (2009) 2812-2817.

[17] H.G.F. Winkler, Bedeutung der Korngrössen-verteilung und Mineral-bestandes von tonnen für die Herstellung 
grobkeramischer Erzeugnisse, Ber. Der DKG 31 (1954) 337-343.

[18] M. Arsenović, Z. Radojević, S. Stanković, Removal of toxic metals from industrial sludge by fixing in brick structure, Constr. Build. Mat. 37 (2012) 7-14.

[19] R.F. Lopez, Calcined Clayey Soils as a Potential Replacement for Cement in Developing Countries, , PhD Thesis, École Polytechnique Fédérale de Lausanne, Lausanne 2009 (http://biblion.epfl.ch/EPFL/theses/2009/4302/ /EPFL_TH4302.pdf).

[20] T.B. Novaković, Lj.S. Rožić, Z.M. Vuković, S.P. Petrović, Uticaj dodatka polietilen-glikola u lantana na mehanizam sinterovanja aluminijum-oksida dobijenog sol-gel postupkom, Hem. Ind. 65(4) (2011) 355-362 (in Serbian).

[21] A. Tretau, E. Rimpel, Ullmann's Encyclopedia of Industrial Chemistry, Construction Ceramics, Wiley Online Library, DOI:10.1002/14356007.a07_425.pub2, 2011.

[22] G.W.A. Nyakairu, H. Kurzweil, C. Koeberl, Mineralogical, geochemical, and sedimentological characteristics of clay deposits from central Uganda and their applications, J. Afr. Earth. Sci. 35 (2002) 123-134.

[23] K. Jeridi, M. Hachani, W. Hajjaji, B. Moussi, M. Medhioub, A. López-Galindo, F. Kooli, F. Zargouni, J. Labrincha, F. Jamoussi, Technological behaviour of some Tunisian clays prepared by dry ceramic processing, Clay Miner. 43 (2008) 339-350.

[24] V. Valanciene, R. Siauciunas, J. Baltusnikaite, The influence of mineralogical composition on the colour of clay body, J. Eur. Ceram. Soc. 30 (2010) 1609-1617.
[25] G. Piltz, Untersuchung der Möglichkeiten der Aufhellung der Brennfarben von Ziegelrohstoffen, Westdt. Verl., Köln, 44 S.m.Abb. Nordrhein-Westfalen: Forschungsberichte, 1964.

[26] P. Bormans, Ceramics are more than clay alone, Cambridge International Science Publishing, 2003.

[27] S. Meseguer, F. Pardo, M.M. Jordan, T. Sanfeliu, I. González, Ceramic behaviour of five Chilean clays which can be used in the manufacture of ceramic tile bodies, Appl. Clay Sci. 47 (2010) 372-377.

[28] Ž. Lalic, M. Arsenovic, Đ. Janackovic, M. Vasic, Z. Radojevic, Influence of increased temperature on clay fast drying process. Rev. Rom. Mat. 39 (2009) 175-179.

[29] K.Y. Chiang, P.H. Chou, C.R. Hua, K.L. Chien, C. Cheeseman, Lightweight bricks manufactured from water treatment sludge and rice husks, J. Hazard. Mater. 171 (2009) 76-82.

[30] M. Sutcu, S. Akkurt, The use of recycled paper processing residues in making porous brick with reduced thermal conductivity, Ceram. Int. 35 (2009) 2625-2631.

[31] M. Raimondo, M. Dondi, G. Davide, G. Guarini, F. Mazzanti, Predicting the initial rate of water absorption in clay bricks, Constr. Build. Mater. 23 (2009) 2623-2630.

[32] F. Singer, S.S. Singer, Industrial Ceramics, Chapman and Hall Ltd., London, 1963.

[33] J.A. de la Casa, M. Lorite, J. Jiménez, E. Castro, Valorization of wastewater from two-phase olive oil extraction in fired clay brick production, J. Hazard. Mater. 169 (2009) 271-278. 


\section{IZVOD}

\section{OPEKARSKE GLINE IZ SRBIJE: PRIMENA U PROIZVODNJI GRUBE KERAMIKE}

Milica V. Arsenović ${ }^{1}$, Lato L. Pezo ${ }^{2}$, Zagorka M. Radojević ${ }^{1}$, Slavka M. Stanković ${ }^{3}$

${ }^{1}$ Institut za ispitivanje materijala IMS, Bulevar vojvode Mišića 43, 11000 Beograd, Srbija

${ }^{2}$ Univerzitet u Beogradu, Institut za opštu i fizičku hemiju, Studentski trg 12, 11000 Beograd, Srbija

${ }^{3}$ Univerzitet u Beogradu, Tehnološko-metalurški fakultet, Karnegijeva 4, 11000 Beograd, Srbija

(Naučni rad)

Gline i glineni minerali se, usled mnogih specifičnih osobina pre i nakon pečenja, decenijama koriste kao osnovni materijali za proizvodnju grube kermike. Proučavanje i utvrđivanje mineralnih faza koje su prisutne u materijalu je komplikovano zato što prirodne gline imaju veoma heterogen mineralni sastav. Tokom processa pečenja dolazi do mnogobrojnih transformacija, koje mogu imati ključni uticaj na osobine gotovih opekarskih proizvoda. Osim sastava važni parametri koji opisuju gline su plastičnost, mehanička čvrstoća nakon pečenja, kapacitet upijanja vode, itd. Poznavanje ovih karakteristika pomaže da se optimizuje korišćenje novootvorenih ležišta gline u lokalnoj ili regionalnoj opekarskoj industriji. Istraživanje prikazano u ovom radu je bazirano na ponašanju opekarskih glina iz Srbije, u kojoj postoji važna lokalna opekarska industrija. Otvoreno je pet novih ležišta, uzorci prikupljeni, a zatim su ispitane njihove fizičke, hemijske, mineraloške i thenološke karakteristike, da bi se ocenila njihova eventualna pogodnost kao sirovina za različite opekarske proizvode. Koeficijent plastičnosti prema Feferkornu I osetljivost u sušenju na osnovu Bigo krive su određeni za svaki uzorak. Nakon što su uzorci oblikovani ekstruzijom i adekvatno osušeni, određene su mehaničke karakteristike proizvoda u suvom stanju i urađena je termodilatometrijska analiza. Uzorci oblika pločica, blokčića i kockica su pečeni na temperaturama od 850$-1000{ }^{\circ} \mathrm{C}$ u oksidacionoj atmosferi i pri sporom režimu. Kapacitet upijanja vode i pritisna čvrstoća su određeni da bi se uzorci okarakterisali nakon pečenja, pri čemu su korišćeni linearni regresioni modeli. Matematički alati su korišćeni da se odredi statistički značaj sadržaja makroelemenata, vlage oblikovanja i pritisne čvrstoće suvih uzoraka, prema HSD testu. lako se hemijski i mineraloški sastav uzoraka značajno ne razlikuje, ali sasvim je suprotno što se tiće moguće primene ovih sirovina. Zaključeno je da sve ispitivane opekarske sirovine mogu jednostavno da se uklope u proces proizvodnje grube keramike.
Ključne reči: Opekarska glina • Tehnološke karakteristike • Primena 